\title{
RESEARCH
}

Open Access

\section{Autologous adipose-derived stem cells for the treatment of complex cryptoglandular perianal fistula: a prospective case-control study}

Yang Zhang ${ }^{1,2+}$, Min $\mathrm{Ni}^{1+}$, Chungen Zhou ${ }^{2+}$, Yehuang Wang ${ }^{1}$, Yaxian Wang ${ }^{2}$, Yang $\mathrm{Shi}^{3}$, Jing $\mathrm{Jin}^{3}$, Rui Zhang ${ }^{2}$ and Bin Jiang ${ }^{1^{*}}$ (D)

\begin{abstract}
Background: Complex cryptoglandular perianal fistula (CPAF) is a kind of anal fistula that may cause anal incontinence after surgery. Minimally invasive surgery of anal fistula is constantly emerging. Over the past 20 years, there are several sphincter-sparing surgeries, one of which is autologous adipose-derived stem cell (ADSC) transplantation. However, to date, there is no study regarding the treatment of complex CPAF with ADSC in China. This is the first study in China on the treatment of complex CPAF with ADSC to evaluate its safety and efficacy.

Methods: Totally, 24 patients with complex CPAF were enrolled in this prospective case-control study from January 2018 to December 2019 in the National Colorectal Disease Center of Nanjing Hospital of Chinese Medicine Affiliated to Nanjing University of Chinese Medicine. Patients were divided into ADSC group and endorectal advancement flap (ERAF) group according to their desire. The healing of fistulas (healing of all treated fistulas at baseline, confirmed by doctor's clinical assessment and magnetic resonance imaging or transrectal ultrasonography) was evaluated at week 12 after treatment. In addition to their safety evaluation based on adverse events monitored at each follow-up, the patients were also asked to complete some scoring scales at each follow-up including pain score with visual analog score (VAS) and anal incontinence score with Wexner score.

Results: The closure rates within ADSC group and ERAF group at week 12 were 54.55\% (6/11) and 53.85\% (7/13), respectively, without significant difference between them. VAS score in ADSC group was significantly lower than that in ERAF group at the 5 th day postoperatively $[1(0,2)$ VS $2(2,4), p=0.011]$, but no differences were observed at the other time. Wexner score of all patients was not increased with no significant differences between the two groups. Adverse events were observed fewer in ADSC group (27.27\%) than that in ERAF group (53.85\%), but there was no significant difference between them.

(Continued on next page)
\end{abstract}

\footnotetext{
* Correspondence: jbfirsth@aliyun.com

${ }^{\dagger}$ Yang Zhang, Min Ni, and Chungen Zhou contributed equally to this work (shared first authorship).

'National Colorectal Disease Center of Nanjing Hospital of Chinese Medicine Affiliated to Nanjing University of Chinese Medicine, Nanjing 210022, Jiangsu Province, China

Full list of author information is available at the end of the article
}

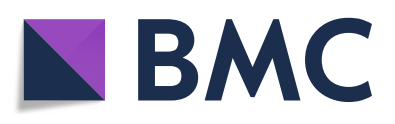

( ) The Author(s). 2020 Open Access This article is licensed under a Creative Commons Attribution 4.0 International License, which permits use, sharing, adaptation, distribution and reproduction in any medium or format, as long as you give appropriate credit to the original author(s) and the source, provide a link to the Creative Commons licence, and indicate if changes were made. The images or other third party material in this article are included in the article's Creative Commons licence, unless indicated otherwise in a credit line to the material. If material is not included in the article's Creative Commons licence and your intended use is not permitted by statutory regulation or exceeds the permitted use, you will need to obtain permission directly from the copyright holder. To view a copy of this licence, visit http://creativecommons.org/licenses/by/4.0/. The Creative Commons Public Domain Dedication waiver (http://creativecommons.org/publicdomain/zero/1.0/) applies to the data made available in this article, unless otherwise stated in a credit line to the data. 
(Continued from previous page)

Conclusion: This study indicated safety and efficiency of ADSC for the treatment of complex CPAF in the short term, which is not inferior to that of ERAF. ADSC may provide a promised and potential treatment for complex CPAF conforming to the future of the treatment, which is reconstruction and regeneration.

Trail registration: ChiCTR, ChiCTR1800014599. Registered 23 January 2018-retrospectively registered, http://www. chictr.org.cn/showproj.aspx?proj=24548

Keywords: Autologous adipose-derived stem cells, Endorectal advancement flap, Complex cryptoglandular perianal fistula, Efficacy, Safety

\section{Introduction}

Perianal fistula is one of the common colorectal diseases with an incidence rate between 1.1 and 2.2 per 10,000 persons per year, which is caused mainly by infection of anal glands $[1,2]$. Although most patients can be cured by surgical operation, the treatment of complex anal fistula remains a big challenge because of high lesion location, pipe bend, and dead space, with a high rate of recurrence and frequent side effects, especially as fecal incontinence [3-5]. Minimally invasive surgery of anal fistula is an emergence, and there are several sphinctersparing surgeries in the past 20 years, but the most suitable surgical treatment has not been determined $[6,7]$.
Adipose-derived stem cell (ADSC) is a population of pluripotent cells derived from adipose tissue [8]. It has been widely used in clinical practice $[9,10]$ including diabetic foot, inflammatory bowel disease, and osteoarthritis, because of its many advantages compared with other sources of stem cells (Fig. 1) [11-13]. Recently, ADSC, a new biotechnology, has also been reported as a safe and effective treatment of complex cryptoglandular perianal fistula (CPAF) in several previously published literatures (Table 1) [14-19]. We previously reported the experience of ADSC in the treatment of Crohn's fistulain-ano and concluded that it has the following advantages: protecting anal function of patients, relieving pain,

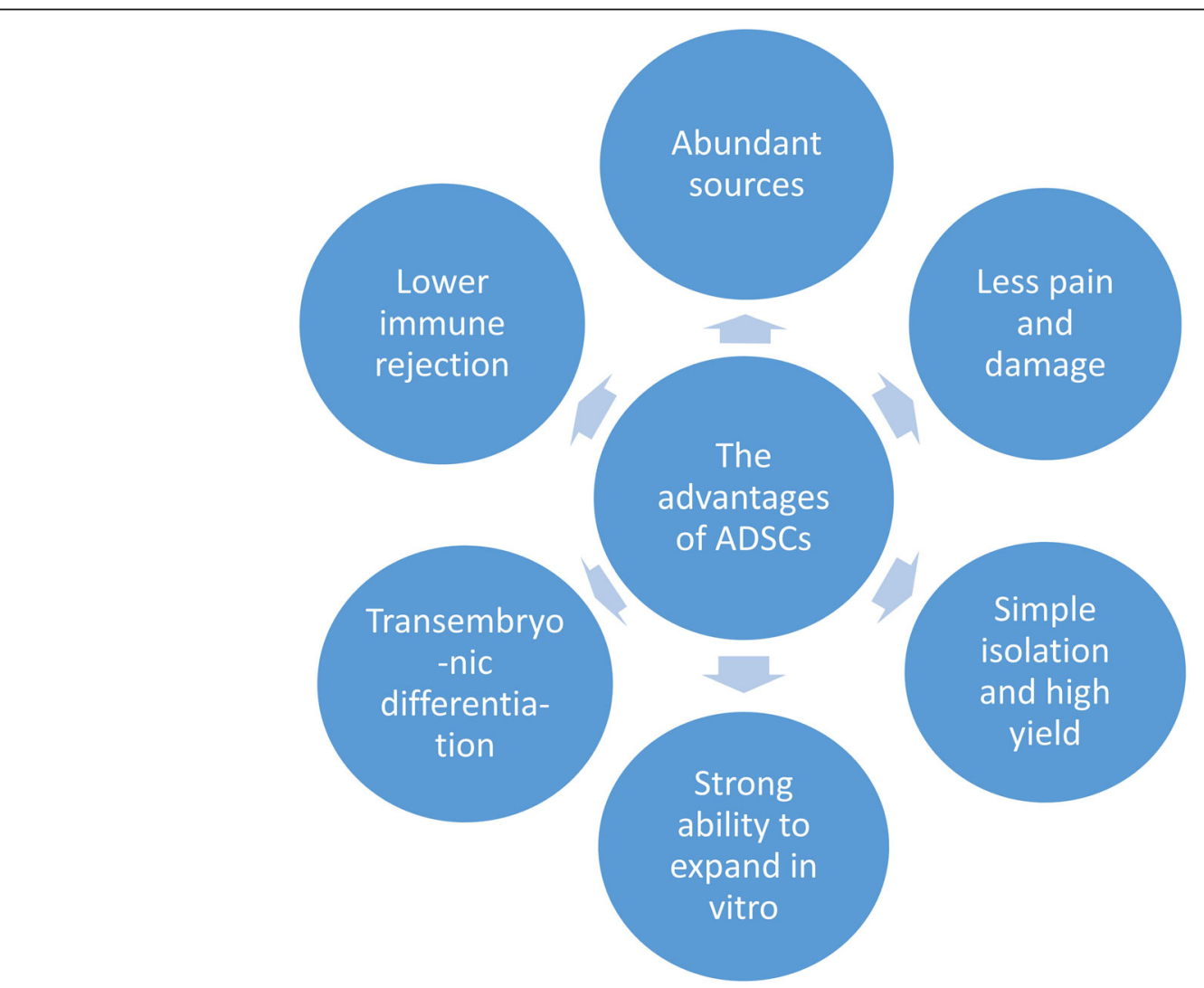

Fig. 1 The advantages of ADSCS 
Table 1 The situation of ADSC in the treatment of CPAF

\begin{tabular}{|c|c|c|c|c|c|c|c|}
\hline Author & Year & Country & Therapy & $\begin{array}{l}\text { Number } \\
\text { of cases }\end{array}$ & Follow-up time & $\begin{array}{l}\text { Healing } \\
\text { rate (\%) }\end{array}$ & $\begin{array}{l}\text { Incontinence } \\
\text { rate (\%) }\end{array}$ \\
\hline Garcia-Olmo D et al. [14] & 2009 & Spain & $\mathrm{ADSC}+\mathrm{FG}$ & 17 & 8 weeks & 70.59 & 0 \\
\hline Herreros MD et al. [15] & 2012 & Spain & $\begin{array}{l}\text { A: ADSC } \\
\text { B: ADSC+FG }\end{array}$ & $\begin{array}{l}\text { A: } 64 \\
\text { B: } 60\end{array}$ & 1 year & $\begin{array}{l}\text { A: } 57.1 \\
\text { B: } 52.4\end{array}$ & 0 \\
\hline Borowski DW et al. [16] & 2012 & England & $\mathrm{ADSC}+\mathrm{ERAF}$ & 3 & 2 to 3 years & 100 & 0 \\
\hline Choi S et al. [17] & 2017 & Korea & ADSC & 13 & 8 weeks & 69.2 & 0 \\
\hline Topal U et al. [18] & 2019 & Turkey & ADSC & 10 & 9 months & 70 & 0 \\
\hline Garcia-Arranz M et al. [19] & 2020 & Spain & CPAF & 23 & 2 years & 50.0 & 0 \\
\hline
\end{tabular}

FG fibrin glue

allowing a quick recovery, being well-tolerated, and improving the quality of life during postoperative period [20]. Furthermore, we conducted a clinical study on ADSC in the treatment of complex CPAF. The aim of this study was to evaluate the efficacy and safety of autologous ADSCs for treatment of complex CPAF compared with the operation of ERAF.

\section{Materials and methods}

\section{Study population}

Eligible participants were adult patients with complex CPAF hospitalized in Nanjing Hospital of Chinese Medicine from January 2018 to December 2019. The inclusion and exclusion criteria were presented in Fig. 2.

\section{Study protocol}

We designed and conducted according to the principles of the Declaration of Helsinki. This study was reviewed and approved by the Ethics Review Committee of Nanjing Hospital of Chinese Medicine (Ethics Review No. KY2018011) and was registered in the China Clinical Trials Registry (No. ChiCTR1800014599). Written informed consent was obtained from each patient before enrollment.

This study was a prospective case-control study to evaluate the safety and efficacy of ADSC in the treatment of complex CPAF. The patients were divided into ADSC group and ERAF group according to their desire. All the patients in the ADSC group received ADSC

\section{Inclusion criteria}

\author{
1.Patients with both genders, $\geq 18$ \\ years.
}

2.Diagnosis of CPAF, which meet the criteria of clinical practice guideline for the management of anorectal abscess, fistula-in-ano, and rectovaginal that was published by American Society of Colon and Rectal Surgeons in 2016.

2.Patient with CPAF should be in a period of non acute inflammation 6 points.

3. There is no evidence of cancer or precancerous lesions in enteroscopy 1 year before admission.

4.Good overall health.

$$
\text { 5.Signature of informed consent. }
$$

\section{Exclusion criteria}

1.Acute infection stage of anal fistula (immature fistula).

\section{Patient with fistula diameter > $2 \mathrm{~cm}$}

3.Patient diagnosed with inflammatory bowel disease.

4.Patients with infectious diseases.

5.Patients who were allergic to anesthetics.

\section{Patients who cannot tolerate liposuction.}

7.Patients who were pregnant or were trying to become pregnant.

8.Patient participating in other clinical trials within the first 3 months 
treatment, while patients in the ERAF group received ERAF treatment. Each patient was followed up for a minimum of 12 weeks after the last treatment to evaluate the safety and efficacy. Figure 3 shows the flow chart of the study.

\section{Treatment of ADSC group}

The procedure of liposuction (Fig. 4a), fistula preparation (Fig. 4b), preparation of ADSCs (Fig. 5), and injection of ADSC (Fig. 4c) is the same as that of ADSC treatment of Crohn's fistula-in-ano which we have reported [20].

Firstly, a plastic surgeon used the "syringe liposuction" introduced by Pierre Fournie [21] to suck fat from the patient's lower abdomen or inner and outer thighs under swelling anesthesia. In the immediate aftermath of the liposuction, patients received fistula preparation more than 2 weeks before ADSC injection, which included fistula exploration, curettage, and drainage with seton. Then, the fat was separated, cultured, proliferated, and identified for 2 weeks at Jiangsu Decon Bio-science Technologies Company Ltd. Next, all the epithelial tissues of the fistulas were removed, and internal openings were closed with 2-0 Vicryl. Subsequently, ADSCs with the concentration of $5 \times 10^{6}$ cells $/ \mathrm{ml}$ were injected into all quadrants around the internal opening and tract of fistulas repeatedly ( $>4$ times) and uniformly according to the diameter and length of fistulas measured by MRI and clinical evaluation. One milliliter of ADSCs/cm was injected when the diameter was less than $1 \mathrm{~cm}$, and $2 \mathrm{ml}$ $\mathrm{ADSCs} / \mathrm{cm}$ was injected with the diameter ranging from
1 and $2 \mathrm{~cm}$. Finally, ADSCs with the concentration of $1 \times 10^{6}$ cells $/ \mathrm{ml}$ were infused into the fistula and the external opening was closed. In addition, if the fistula had not healed at 8 weeks, the patient would receive a second treatment according to the same protocol, who agreed to receive injection again with the concentration of $1 \times 10^{7}$ cells $/ \mathrm{ml}$.

\section{Treatment of ERAF group}

This technique was performed under intraspinal anesthesia with the patient in the lateral position. The full-thickness flap, which consists of mucosa, submucosa, and some circular muscle fibers, was moved $4-5 \mathrm{~cm}$ from the dentate line to the cephalic side. The bottom of the flap was at least twice as wide as its top to ensure an adequate blood supply to the distal tissue. After the resection of the distal part of the flap with the internal opening and the curettage of the fistula, the internal portion of the fistula was sutured with 2-0 Vicryl in figure-of-eight suture. The flap was sutured without tension to cover the internal opening with 2-0 Vicryl. (Fig. 4d).

\section{Assessments}

The same variable definitions and evaluation procedures were applied to evaluate the safety and efficacy for all participants in both intervention and control groups.

\section{Efficacy}

If the fistula had not healed at 8 weeks, the patient received a second dose of fibrin glue or fibrin glue plus

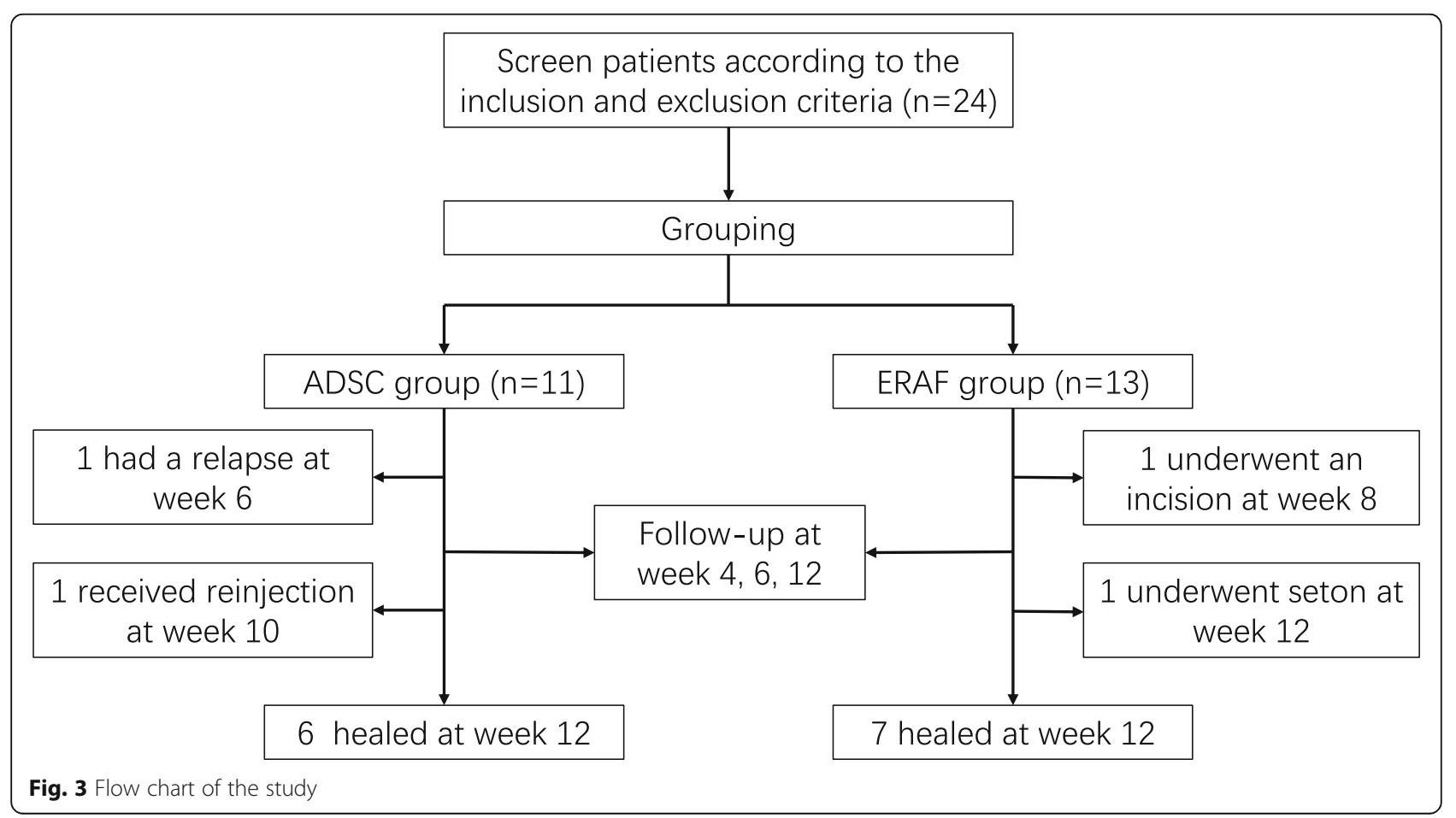




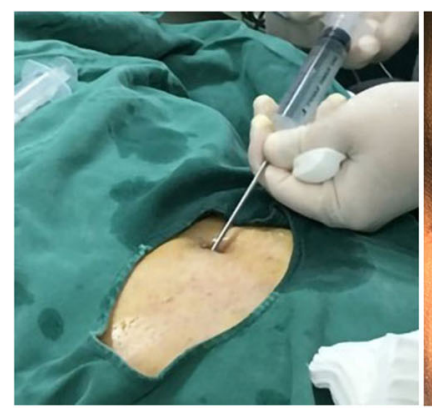

(a)

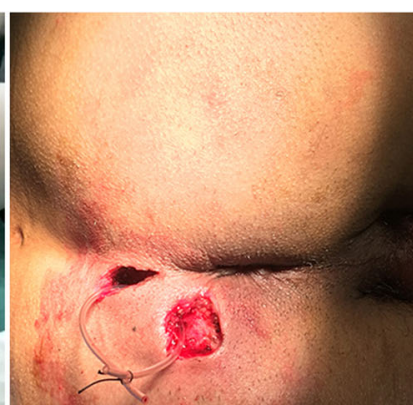

(b)

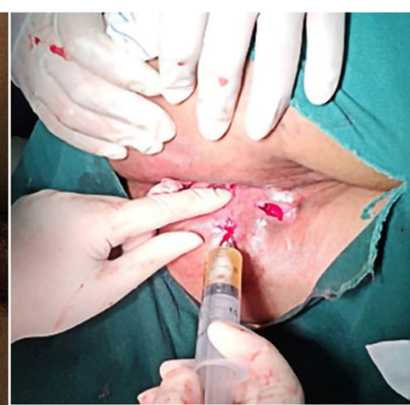

(c)

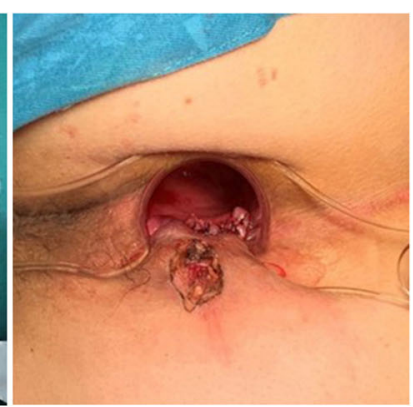

(d)

Fig. 4 Treatment of patients. a Liposuction. b Fistula preparation. c Injection of ADSCs. d Suture of ERAF

ASCs (twice the dose of the first treatment, 4 [times] 10 million) and was reassessed according to the same protocol.

The primary endpoint for efficacy was defined as the proportion of patients whose fistula was closed at week
12 postoperatively. The closure of the fistula was evaluated through clinical evaluation and magnetic resonance imaging (MRI) or endorectal ultrasonography (ERUS) at 12 weeks postoperatively. Closure was defined as the complete epithelialization of external openings (i.e., no pus

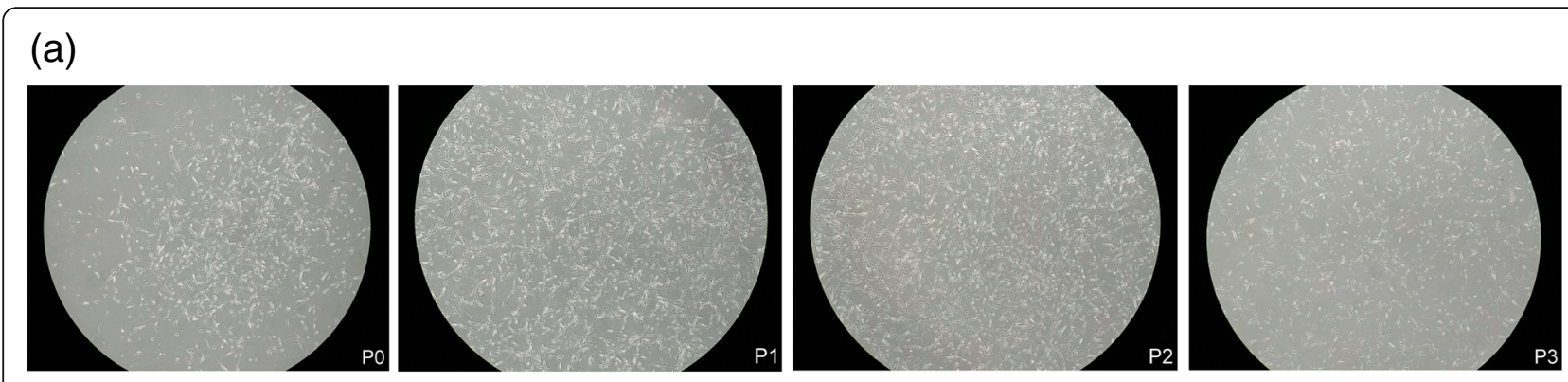

(b)
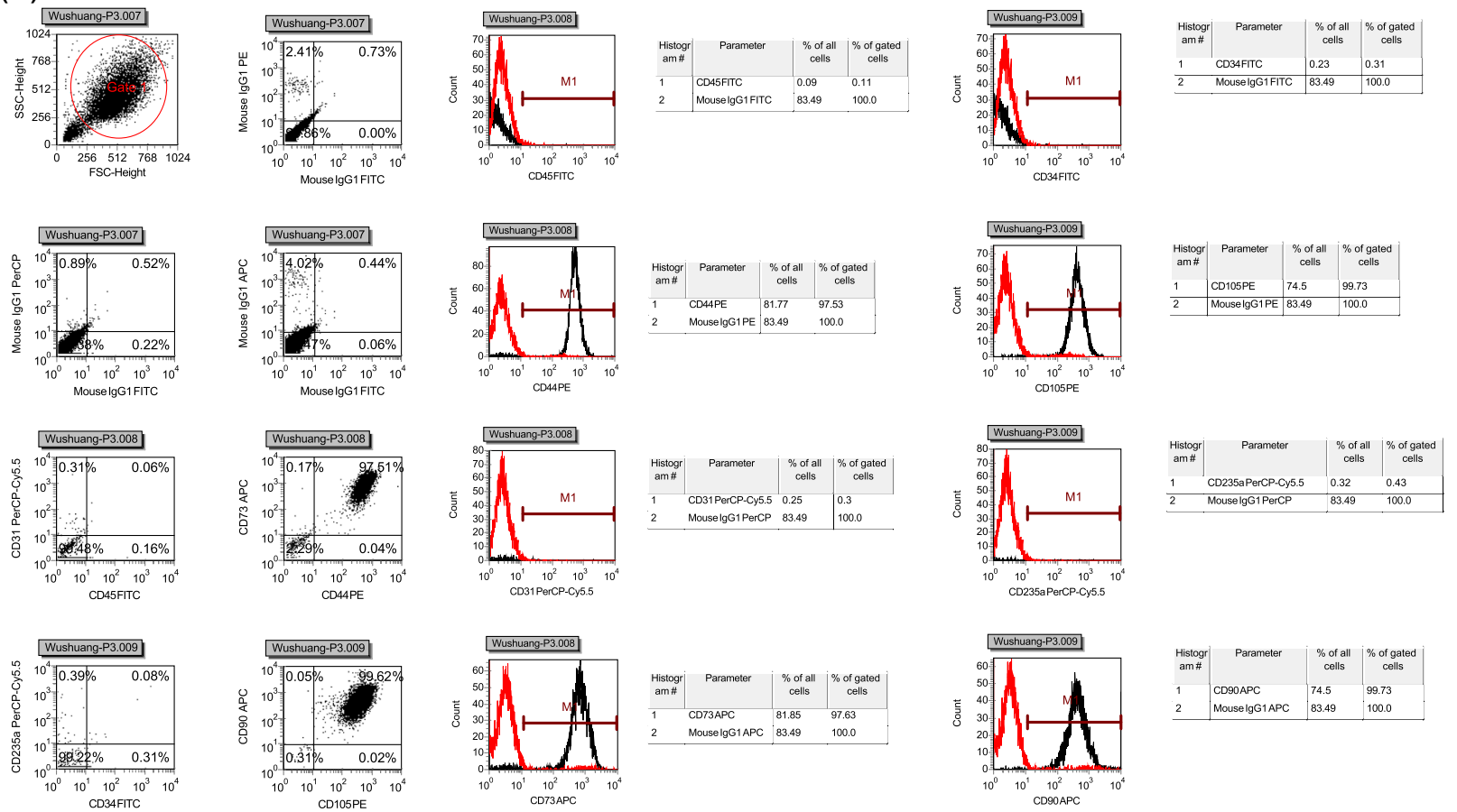

Fig. 5 Preparation of ADSCs. a Cell morphology of each generation. $\mathbf{b}$ Cell phenotype of ADSCs 


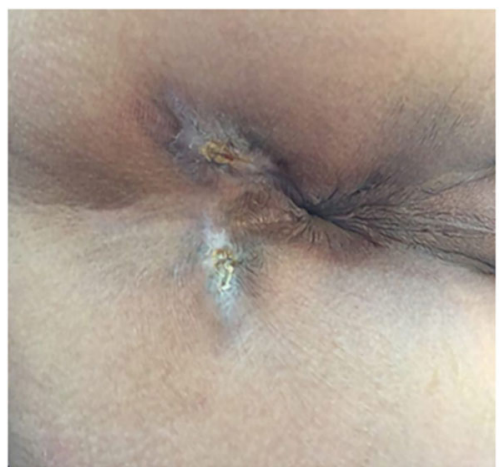

(a)

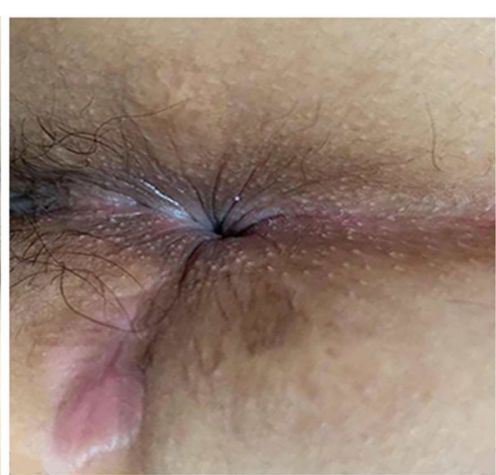

(b)

Fig. 6 The closure of the fistula at week 12. a The closure of the fistula with ADSC. $\mathbf{b}$ The closure of the fistula with ERAF

outflow from the external openings under any circumstances, Fig. 6) and no evidence of fistulas in MRI or ERUS.

The secondary endpoints for efficacy included pain score with visual analog score (VAS) and anal incontinence score with Wexner score, which were completed by patients at each follow-up.

\section{Safety}

Safety was assessed by determining the incidence of adverse events (AEs) and serious AEs (SAEs). During each follow-up, the AEs of patients were monitored. AEs included fever (axillary temperature $>38^{\circ} \mathrm{C}$ ), perianal pain (VAS score $>5$ points), anal distention, uroschesis, and secretion.

\section{Statistical analyses}

The continuous measurements, obeying normal distribution, were presented with means and SD; otherwise, they were described with median (quartile) [M (p25, p75)]. For categorical variables, they were described as percentages and $95 \%$ confidence interval (CI). $T$ test or non-parametric test was used to make comparisons of continuous variables between sub-groups, while chisquare test or Fisher exact test was applied to make comparisons for categorical measures in this study. $P<$ 0.05 was considered statistically significant in all statistical tests. All statistical analyses were performed with SPSS 22.0 software.

\section{Results}

\section{Patients characteristics}

Among the 24 patients, there were 4 women and 20 men, with a mean (standard deviation, SD) age of $34.25 \pm 7.97$ years. There was no significant difference in selected characteristics between the two groups at baseline (Table 2). All the patients in both groups completed the 12-week follow-ups. The average volume of fat extracted from the

Table 2 Characteristics of patients at baseline

\begin{tabular}{|c|c|c|}
\hline Contents & $\operatorname{ADSC} \operatorname{group}(n=11)$ & $\operatorname{ERAF} \operatorname{group}(n=13)$ \\
\hline \multicolumn{3}{|l|}{ Sex } \\
\hline Male & $10(90.91 \%)$ & $10(76.92 \%)$ \\
\hline Female & $1(9.09 \%)$ & $3(23.08 \%)$ \\
\hline Age (year) & $35.73 \pm 7.54$ & $33.00 \pm 8.42$ \\
\hline BMI $\left(\mathrm{kg} / \mathrm{m}^{2}\right)$ & $25.30 \pm 4.98$ & $23.91 \pm 2.98$ \\
\hline Volume of fat (mL) & $52.73 \pm 28.23$ & - \\
\hline Number of cells ( $\Delta 10^{6}$ cells) & $89.70 \pm 57.42$ & - \\
\hline VAS $^{\S}$ & $0.8 \pm 1.0$ & $1.1 \pm 1.0$ \\
\hline Wexner" & $1.2 \pm 1.3$ & $1.5 \pm 0.7$ \\
\hline \multicolumn{3}{|l|}{ Classification of CPAF (Parks) } \\
\hline Transsphincteric & $5(45.45 \%)$ & $7(53.85 \%)$ \\
\hline Suprasphincteric & $6(54.55 \%)$ & $6(46.15 \%)$ \\
\hline
\end{tabular}

Data are mean (SD) or number (\%). Percentages might not always add up to exactly $100 \%$ as a result of rounding. $B M I$ body mass index. ${ }^{5}$ Score ranges from 0 to 10; higher scores suggest more severe degree of pain. "Score ranges from 0 to 20; higher scores suggest more severe degree of anal incontinence 
patients in ADSC group was $52.73 \pm 28.23 \mathrm{~mL}$ and number of ADSCs was $(89.70 \pm 57.42) \times 10^{6}$ cells.

\section{Efficacy \\ Primary endpoint}

At week 12, there were no significant differences between ADSC group and ERAF group (6/11 [54.55\%] vs 7/13 [53.85\%], difference [95\% CI] 0.7 percentage points [ -34.38 to 35.27], $p=1.000$; Fig. $7 \mathrm{a}$ and Table 3). There were also no significant differences between the different types of CPAF in each group $(4 / 5$ [80.00\%] vs $2 / 6$ [33.33\%], 5/7 [71.43\%] vs $2 / 6$ [33.33\%], respectively; difference $[95 \% \mathrm{CI}] 46.67$ percentage points [-9.42 to 75.44], $p=0.242$; and 38.10 percentage points [ -12.97 to 69.30], $p=0.286$; Fig. 7b). In addition, the difference in the closure rate between the two stratification groups was also not significant (4/5 [80.00\%] vs $5 / 7$ [71.43\%], 2/ 6 [33.33\%] vs $2 / 6$ [33.33\%], respectively; difference [95\% CI] 8.57 percentage points [ -35.80 to 47.70 ], $p=1.000$ and 0.00 percentage points [ -43.64 to 43.64 ],$p=1.000$; Fig. $7 \mathrm{c}$ and Table 3).

\section{Secondary endpoints}

VAS score Although VAS score seemed lower for patients in ADSC group relative to those in ERAF group, the significant differences between the two groups was examined only at the 5 th day postoperatively $[3(0,5)$ VS $2(2,4), p=0.575 ; 1(0,2)$ VS $2(2,4), p=0.011 ; 0(0,1)$ VS $0(0,2), p=0.332$; $0(0,0)$ VS $0(0,1.5), p=0.086$; Fig. $8 \mathrm{a}]$.

Wexner score There was no increase in Wexner score of all patients. And there were no significant differences between the groups at all follow-up points (Fig. 8b).

\section{Safety}

Over the 12-week follow-up, there were no significant differences in the percentage of patients who experienced AEs in ADSC and ERAF group (3/11 [27.27\%] and 7/13 [53.85\%], respectively, difference $\left[\begin{array}{lll}95 \% & \mathrm{CI}\end{array}\right] 26.57$ percentage points [ -11.74 to 55.45], $p=0.240$; Table 4). None of patients withdrew from the 12-week study period due to AEs. There were no serious AEs occurred in all patients. No deaths occurred during the trail.

\section{Discussion}

The surgical treatment of CPAF is a huge challenge for colorectal surgeons. The biggest risk is anal incontinence caused by sphincter injury. It is reported that the incidence of anal incontinence after fistulotomy of complex CPAF is up to $40 \%$ [22]. Therefore, with the continuous development of the technology, the principle of surgical treatment of fistula-in-ano has become to cure fistula-inano while decreasing the injury of anal function possibly [3]. As a result, emergence of various sphincter-sparing surgeries has been a trend and necessity now.

ERAF is a classic sphincter-sparing operation for the treatment of complex CPAF, and its healing rate is 66$87 \%$ [3]. So it is recommended for the treatment of fistula-in-ano by American Society of Colon and Rectal Surgeons (ASCRS) and Italian Society of Colorectal Surgery (Società Italiana di Chirurgia Colo-Rettale, SICCR) (Strong recommendation based on moderate-quality evidence, 1B) [3, 23]. Although the sphincter is not been incised, it is still reported that $13.2 \%$ of patients with CPAF suffer from mild to moderate incontinence in a systematic review, and anorectal manometry found that the anal canal resting pressure and anal canal squeeze pressures are decreased postoperatively [3, 24, 25].

The study of fistula-in-ano's treatment with mesenchymal stem cells (MSCs) had become a research hotspot, which had a great prospect and potential future application since Garcia-Olmo et al. [26] And the American Food and Drug Administration and European Union approved CX601 (human allogeneic ADSC) for the treatment of Crohn's fistula-in-ano in 2017 and 2018 respectively. Therefore, we believed that ADSC has a potential future application in the treatment of CPAF according to several previously published literatures (Table 1) [14-19].

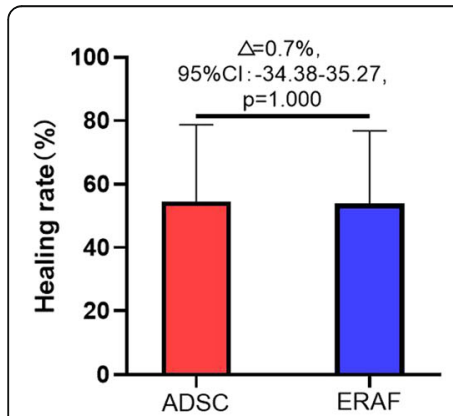

(a)

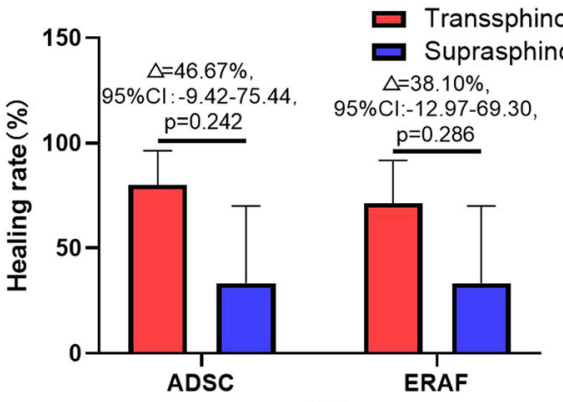

(b)

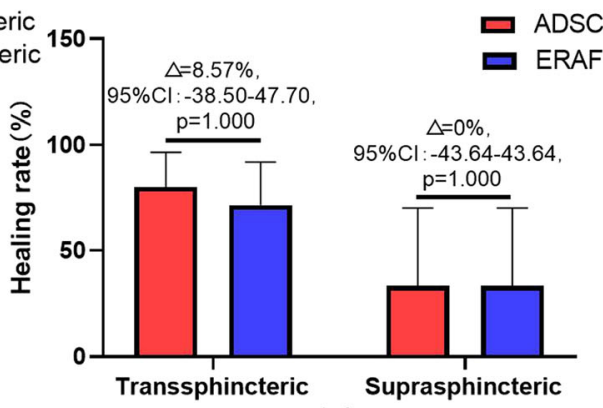

(c)

Fig. 7 Primary endpoint. a Closure rate at week 12. b Closure rate of different types of CPAF in each group. c Closure rate of different types of CPAF 
Table 3 Primary endpoint

\begin{tabular}{|c|c|c|c|c|c|c|c|c|c|}
\hline \multirow[t]{2}{*}{ Patients } & \multicolumn{3}{|l|}{ ADSC } & \multicolumn{3}{|l|}{ ERAF } & \multicolumn{3}{|l|}{ Analysis } \\
\hline & Total & No. closed & $\%$ & Total & No. closed & $\%$ & Difference & $95 \% \mathrm{Cl}$ & $P$ value \\
\hline All cases & 11 & 6 & 54.55 & 13 & 7 & 53.85 & 0.7 & $-34.38-35.27$ & 1.000 \\
\hline \multicolumn{10}{|l|}{ Subgroup analyze } \\
\hline Transsphincteric & 5 & 4 & 80.00 & 7 & 5 & 71.43 & 8.57 & $-38.50-47.70$ & 1.000 \\
\hline Suprasphincteric & 6 & 2 & 33.33 & 6 & 2 & 33.33 & 0 & $-43.64-43.64$ & 1.000 \\
\hline
\end{tabular}

Cryptoglandular infection is the key cause of CPAF, which provide a free channel for infection to pass from the anal lumen deep into the sphincter muscles [27]. Therefore, the management of internal openings to block the source of infection from the anal lumen is the key to the treatment of CPAF. It was reported that MSC can inhibit inflammation by significantly reducing the secretion of pro-inflammatory cytokines such as tumor necrosis factor (TNF) and interleukin (IL)-1 $\beta$ and increasing the production of anti-inflammatory cytokines such as IL-10 $\beta$ [28]. It was also reported that MSC can selectively migrate to the site of tissue injury and inflammation [29-31]. So, we believed that ADSC can promote tissue regeneration and repair through its paracrine, which migrates to the site of tissue injury and inflammation selectively and reduces the degree of fibrosis by inhibiting inflammatory. And it can strengthen the management of the internal opening to block the source of infection from the anal lumen.

To our knowledge, this is the first report of a study in which ADSCs were used to treat CPAF in China. Our study indicated that the closure rate of ADSC was not inferior to that of ERAF at week 12 (54.55\% VS 53.85\%, $p=1.000$ ). And it was similar to some other studies [15, 19]. As Cho et al. [32] and Choi et al. [17] reported, we also thought that some failure of the cases with ADSC in this study may be caused by poor control of infection. However, we supposed that the principal reason is the lack of the experience of operation, because we did not have any reference of procedures due to the first study in China. In addition, it seems to be lower that the short-term closure rate compared with our previous study in the patients with Crohn's disease [20], which may be caused by the small sample size.

Minimally invasive surgery is a trend of fistula-in-ano's surgical treatment, which focuses on enhanced recovery and functional protection. On the one hand, the results showed that the postoperative pain of patients was significantly decreased on the 5th day and almost returns to normal at week 4. Although there was no significant difference in VAS score between the two groups due to the limitation of sample size, and VAS score of ADSC group was higher than that of ERAF group at day 1 because a patient reported his score was 10. We still believed that ADSC has an advantage in pain relief. On the other hand, there was no incontinence due to the injury of sphincter in the study as previously literatures reported (Table 1) [14-19]. The damage of anal function after the operation of ERAF may be related to the stretch injuries to the muscle and nerve fibers caused by significant retraction and manipulation of the anus [33]. However, ADSC can protect the anal sphincter better because it does not need significant retraction and manipulation of the anus compared with ERAF.

Autologous ADSC can avoid autoimmune rejection and ensure the safety of treatment in this study. The study showed that ADSC is well tolerated and there was

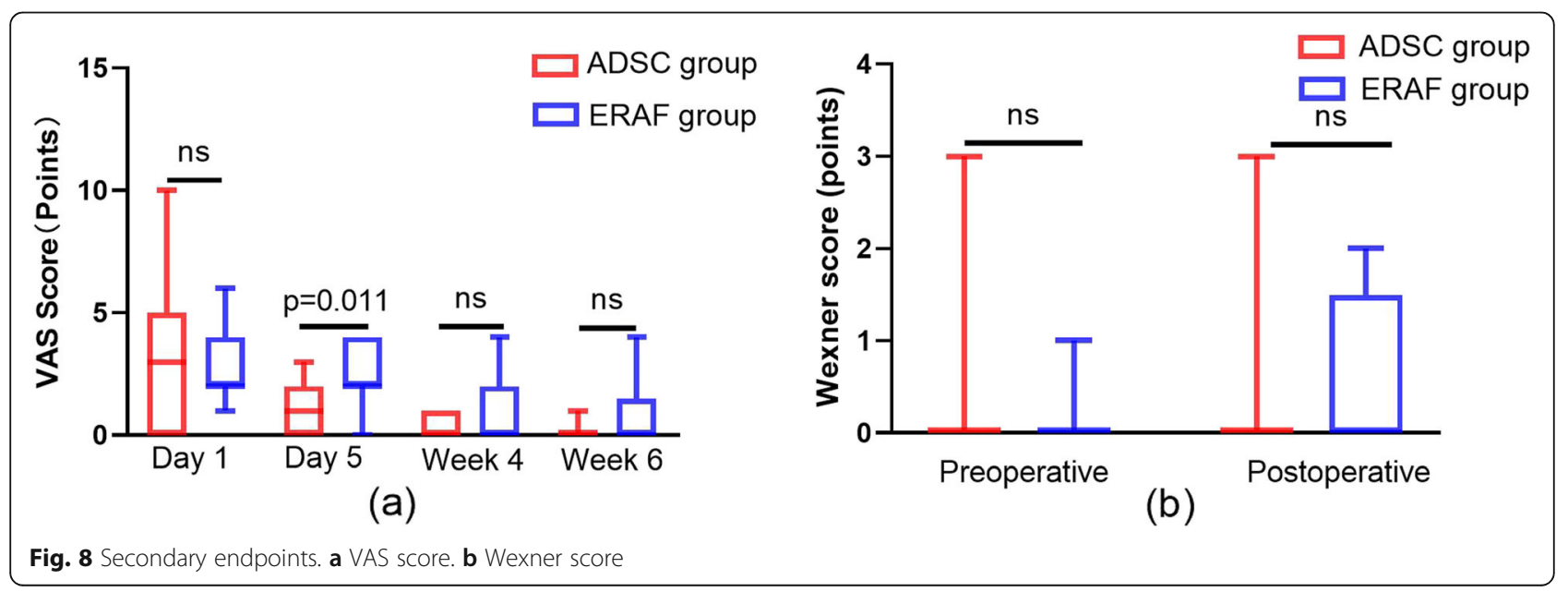


Table 4 Safety evaluation based on adverse events observed during 12-week follow-up

\begin{tabular}{lll}
\hline Contents & ADSC group $(n=11)$ & ERAF group $(n=13)$ \\
\hline Overall & 3 & 7 \\
AEs & & \\
$\quad$ Perianal pain & 3 & 1 \\
Anal distention & 0 & 7 \\
Uroschesis & 0 & 1 \\
SAEs & 0 & 0
\end{tabular}

no evidence of specific adverse events associated with it, which was consistent with the results of other studies [14-19]. The results showed that more than half of the patients in ERAF group appear anal distention in the early postoperative period, which may be related to the retraction, manipulation, and suture of flap, while there was no anal distention in ADSC group and the patients felt more comfortable after operation.

The main limitation in this study had been that small sample size and no randomization have an impact on the results. On the one hand, only 24 cases were enrolled in our study until the end of 2019 because it could not go on this year for various reasons. On the other hand, we had to ask the patients' desire before liposuction because autologous ADSC was used in the study and could not randomize due to medical inform, patients' informed consent, and relevant laws in China. We will conduct large scale randomized controlled trials (RCTs) to evaluate the safety and efficacy of ADSC in the future. Another limitation in this study would be that the follow-up time is short, and only 12 weeks follow-up results were reported in this article due to the short follow-up of some cases. We will continue our follow-up and report the results in the future. Otherwise, high cost of ADSC preparation and two operations limit the promotion and application of ADSC in some degree as we have reported before [20].

In summary, we observed that ADSC is a safe and effective treatment which is not worse than ERAF in the treatment of complex CPAF. It can protect anal function of patients, relieve pain, reduce complications, recover quickly, and provide good tolerance.

\section{Conclusion}

This study indicated safety and efficacy of ADSC for the treatment of complex CPAF in the short term, which is not inferior to that of ERAF. ADSC may provide a promised and potential treatment for complex CPAF conforming to the future of the treatment, which is reconstruction and regeneration.

\section{Abbreviations}

ERAF: Endorectal advancement flap; ADSC: Adipose-derived stem cells; CPAF: Cryptoglandular perianal fistula; MRI: Magnetic resonance imaging;
ERUS: Endorectal ultrasonography; VAS: Visual analog score; AE: Adverse event; SAE: Serious adverse event; ASCRS: American Society of Cataract and Refractive Surgery; SICCR: Società Italiana di Chirurgia Colo-Rettale; MSC: Mesenchymal stem cells; TNF: Tumor necrosis factor; IL: Interleukin; RCT: Randomized controlled trials

\section{Acknowledgements}

We express our sincere appreciation to the patients who participated in this study. And we appreciate to those who helped us, such as Fei Xu, Qi Zhang, Xiaobo Huang, Ting Lu, and Yanlan Wu.

\section{Authors' contributions}

YZ, MN, and CZ contributed equally to this work. YZ designed the study, included the patients, carried out the surgical treatment, prepared the figures, drafted the manuscript, revised the manuscript, and polished the language of the article; MN designed the study, included the patients, revised the manuscript, and polished the language of the article; $C Z$ made the follow-up, collected, analyzed, and interpreted the data, prepared the figures, and drafted the manuscript and revised it. YW included the patients, carried out the surgical treatment, and provided some technical assistance and pertinent proposal on the scheme. YW and RZ made the follow-up, collected and analyzed the data, and prepared the figures. YS and JJ prepared the ADSC and quality control of preparations. BJ is the principal investigator of the funding, who designed and conceived the study, revised the manuscript critically for important intellectual content, and approved the final version to be submitted. All authors read and approved the final version of the manuscript.

\section{Funding}

This work was funded by the Key Medical Science and Technology Development Projects of Nanjing Commission of Health, No. ZKX17034.

\section{Availability of data and materials}

The datasets used and/or analyzed during the current study are available from the corresponding author upon request. After the completion of the trial, all data will be uploaded to China clinical trial registration center.

\section{Ethics approval and consent to participate}

All methods were carried out in accordance with relevant guidelines and regulations. All experimental protocols were approved by the ethics committee of Nanjing Hospital of Chinese medicine Affiliated to Nanjing University of Chinese Medicine (Nanjing, China). Written informed consent was obtained from all study patients.

\section{Consent for publication}

Consent for publication was obtained from all study patients by signing informed consent form in screening. All the authors consent to publish the paper in Stem Cell Research and Therapy.

\section{Competing interests}

The authors declare that they have no competing interests.

\section{Author details}

${ }^{1}$ National Colorectal Disease Center of Nanjing Hospital of Chinese Medicine Affiliated to Nanjing University of Chinese Medicine, Nanjing 210022, Jiangsu Province, China. ${ }^{2}$ Graduate School of Nanjing University of Chinese Medicine, Nanjing 210029, Jiangsu Province, China. ${ }^{3}$ Research Institute of Jiangsu Decon Bio-science Technologies Company Ltd., Nanjing 210000, Jiangsu Province, China.

Received: 22 April 2020 Accepted: 24 October 2020 Published online: 10 November 2020

\section{References}

1. Zanotti C, Martinez-Puente C, Pascual I, et al. An assessment of the incidence of fistula-in-ano in four countries of the European Union. Int J Colorectal Dis. 2007;22:1459-62. https://doi.org/10.1007/s00384-007-0334-7.

2. Sainio P. Fistula-in-ano in a defined population. Incidence and epidemiological aspects; 1984. p. 219-24doi: https://doi.org/10.1097/ 00000478-198412000-00007. 
3. Vogel JD, Johnson EK, Morris AM, et al. Clinical practice guideline for the management of anorectal abscess, fistula-in-ano, and rectovaginal fistula. Dis Colon Rectum. 2016;59:1117-33. https://doi.org/10.1097/DCR. 0000000000000733.

4. Garcia-Aguilar J, Davey CS, Le CT, et al. Patient satisfaction after surgical treatment for fistula-in-ano. Dis Colon Rectum. 2000;43:1206-12. https://doi. org/10.1007/bf02237422

5. Whiteford MH, Kilkenny JR, Hyman N, et al. Practice parameters for the treatment of perianal abscess and fistula-in-ano (revised). Dis Colon Rectum. 2005;48:1337-42. https://doi.org/10.1007/s10350-005-0055-3.

6. Gottgens KW, Smeets RR, Stassen LP, et al. Systematic review and meta-analysis of surgical interventions for high cryptoglandular perianal fistula. Int J Colorectal Dis. 2015;30:583-93. https://doi.org/10.1007/ s00384-014-2091-8.

7. Sugrue J, Mantilla N, Abcarian A, et al. Sphincter-sparing anal fistula repair: are we getting better? Dis Colon Rectum. 2017;60:1071-7. https://doi.org/ 10.1097/DCR.0000000000000885.

8. Minteer DM, Marra KG, Rubin JP. Adipose stem cells: biology, safety, regulation, and regenerative potential. Clin Plast Surg. 2015;42:169-79. https://doi.org/10.1016/j.cps.2014.12.007.

9. Lonardi R, Leone N, Gennai S, et al. Autologous micro-fragmented adipose tissue for the treatment of diabetic foot minor amputations: a randomized controlled single-center clinical trial (MiFrAADiF). Stem Cell Res Ther. 2019; 10:223. https://doi.org/10.1186/s13287-019-1328-4.

10. Ceccarelli S, Pontecorvi P, Anastasiadou E, et al. Immunomodulatory effect of adipose-derived stem cells: the cutting edge of clinical application. Front Cell Dev Biol. 2020;8:236. https://doi.org/10.3389/fcell. 2020.00236 eCollection 2020.

11. Deng J, Shi Y, Gao Z, et al. Inhibition of pathological phenotype of hypertrophic scar fibroblasts via coculture with adipose-derived stem cells. Tissue Eng Part A. 2018;24:382-93. https://doi.org/10.1089/ten TEA.2016.0550.

12. Su X, Lyu Y, Wang W, et al. Fascia origin of adipose cells. Stem Cells. 2016; 34:1407-19. https://doi.org/10.1002/stem.2338.

13. Münch DP. Breast augmentation with autologous fat - experience of 96 procedures with the BEAULI-technique. Handchir Mikrochir Plast Chir. 2013; 45:80-92. https://doi.org/10.1055/s-0033-1343396.

14. Garcia-Olmo D, Herreros D, Pascual I, et al. Expanded adipose-derived stem cells for the treatment of complex perianal fistula: a phase II clinical trial. Dis Colon Rectum. 2009;52:79-86. https://doi.org/10.1007/DCR. ob013e3181973487.

15. Herreros MD, Garcia-Arranz M, Guadalajara H, et al. Autologous expanded adipose-derived stem cells for the treatment of complex cryptoglandular perianal fistulas: a phase III randomized clinical trial (FATT 1: fistula Advanced Therapy Trial 1) and long-term evaluation. Dis Colon Rectum. 2012;55:762-72. https://doi.org/10.1097/DCR.0b013e318255364a.

16. Borowski DW, Gill TS, Agarwal AK, et al. Autologous adipose-tissue derived regenerative cells for the treatment of complex cryptoglandular fistula-inano: a report of three cases. BMJ Case Rep. 2012;2012. https://doi.org/10. 1136/bcr-2012-006988.

17. Choi S, Ryoo SB, Park KJ, et al. Autologous adipose tissue-derived stem cells for the treatment of complex perianal fistulas not associated with Crohn's disease: a phase II clinical trial for safety and efficacy. Tech Coloproctol. 2017;21:345-53. https://doi.org/10.1007/ s10151-017-1630-z.

18. Topal U, Eray IC, Rencuzogullari A, et al. Short-term results of adiposederived stem cell therapy for the treatment of complex perianal fistula A single center experience. Ann Ital Chir. 2019;90:583-9.

19. Garcia-Arranz M, Garcia-Olmo D, Herreros MD, et al. Autologous adipose-derived stem cells for the treatment of complex cryptoglandular perianal fistula: a randomized clinical trial with longterm follow-up. Stem Cells Transl Med. 2020;9:295-301. https://doi.org/ 10.1002/sctm.19-0271.

20. Zhou C, Li M, Zhang Y, et al. Autologous adipose-derived stem cells for the treatment of Crohn's fistula-in-ano: an open-label, controlled trial. Stem Cell Res Ther. 2020;11:124. https://doi.org/10.1186/s13287-020-01636-4.

21. Fournier PF. Liposculpture: the syringe technique. Am J Cosmetic Surg. 1993;10:179-87. https://doi.org/10.1177/074880689301000305.

22. Koperen PJV, Wind J, Bemelman WA, et al. Long-term functional outcome and risk factors for recurrence after surgical treatment for low and high perianal fistulas of cryptoglandular origin. Dis Colon Rectum. 2008;51:147581. https://doi.org/10.1007/s10350-008-9354-9.
23. Amato A, Bottini C, De Nardi $P$, et al. Evaluation and management of perianal abscess and anal fistula: SICCR position statement. Tech Coloproctol. 2020;24:127-43. https://doi.org/10.1007/s10151-019-02144-1.

24. Soltani A, Kaiser AM. Endorectal advancement flap for cryptoglandular or Crohn's fistula-in-ano. Dis Colon Rectum. 2010;53:486-95. https://doi.org/10. 1007/DCR.0b013e3181ce8b01.

25. Uribe N, Balciscueta Z, Minguez M, et al. "Core out" or "curettage" in rectal advancement flap for cryptoglandular anal fistula. Int J Colorectal Dis. 2015; 30:613-9. https://doi.org/10.1007/s00384-015-2133-x.

26. Garcia-Olmo D, Garcia-Arranz M, Garcia LG, et al. Autologous stem cell transplantation for treatment of rectovaginal fistula in perianal Crohn's disease: a new cell-based therapy. Int J Colorectal Dis. 2003;18:451-4. https://doi.org/10.1007/s00384-003-0490-3.

27. Steele SR, Hull TL, Read TE, et al. The ASCRS textbook of colon and rectal surgery. 3rd ed. New York: Springer-Verlag; 2016. https://doi.org/10.1007/ 978-3-319-25970-3.

28. González MA, Gonzalez Rey E, Rico L, et al. Adipose-derived mesenchymal stem cells alleviate experimental colitis by inhibiting inflammatory and autoimmune responses. Gastroenterology. 2009;136:978-89. https://doi.org/ 10.1053/j.gastro.2008.11.041.

29. Devine SM, Cobbs C, Jennings M, et al. Mesenchymal stem cells distribute to a wide range of tissues following systemic infusion into nonhuman primates. Blood. 2003;101:2999-3001. https://doi.org/10.1182/blood-2002-06-1830.

30. Bruck F, Belle L, Lechanteur $\mathrm{C}$, et al. Impact of bone marrow-derived mesenchymal stromal cells on experimental xenogeneic graft-versus-host disease. Cytotherapy. 2013;15:267-79. https://doi.org/10.1016/j.jcyt.2012.09.003.

31. Tanaka F, Tominaga $\mathrm{K}$, Ochi $\mathrm{M}$, et al. Exogenous administration of mesenchymal stem cells ameliorates dextran sulfate sodium-induced colitis via anti-inflammatory action in damaged tissue in rats. Life Sci. 2008;83:7719. https://doi.org/10.1016/j.lfs.2008.09.016.

32. Cho YB, Park KJ, Yoon SN, et al. Long-term results of adipose-derived stem cell therapy for the treatment of Crohn's fistula. Stem Cell Transl Med. 2015; 4:532-7. https://doi.org/10.5966/sctm.2014-0199.

33. Abcarian H, Cintron J, Nelson R. Complications of anorectal surgery \| Perineal Repair of Rectal Prolapse: Springer International Publishing; 2017. doi: https://doi.org/10.1007/978-3-319-48406-8_8.

\section{Publisher's Note}

Springer Nature remains neutral with regard to jurisdictional claims in published maps and institutional affiliations.

Ready to submit your research? Choose BMC and benefit from:

- fast, convenient online submission

- thorough peer review by experienced researchers in your field

- rapid publication on acceptance

- support for research data, including large and complex data types

- gold Open Access which fosters wider collaboration and increased citations

- maximum visibility for your research: over $100 \mathrm{M}$ website views per year

At BMC, research is always in progress.

Learn more biomedcentral.com/submissions 